\title{
The Evidence of Women's Labor Reasons Performing Informal Economic Activities in Palembang, South Sumatera, Indonesia
}

\author{
Mirna Taufik ${ }^{1}$, Monanisa ${ }^{2}$, Nengyanti $^{3}$, Bambang Bemby Soebyakto $^{4}$, Armansyah $^{5}$ \\ \{mirnataufik@yahoo.com ${ }^{1}$, nisamona8@gmail.com ${ }^{2}$, nengyanti@gmail.com ${ }^{3}$, \\ bambangsoebyakto@gmail.com ${ }^{4}$, armagedone77@yahoo.com ${ }^{5}$ \} \\ Population Sciences of Geography Department, PGRI University of Palembang ${ }^{1,2,5}$ \\ Population Sciences at Graduate Program, Sriwijaya University, Palembang ${ }^{3,4}$
}

\begin{abstract}
Recently, women's role in the workfield has increased. Especially with the existence of a gender equality program that makes employment opportunity become equal for both workers, men's and women's. Not infrequently even women are more able to compete and occupy important positions at work. But not a few women's labor are involved in informal sector of workfield. Therefore, this study is aimed to explore the evidence of reasons behind women's labor performing informal economic activity in Palembang, the city in South Sumatera Province of Indonesia.The method used in the study is a quantitative method by collecting data through surveys and interviews. Then the data were analyzed by using a descriptive analysis of frequency that presented in pie charts and descriptions. The findings of evidence through descriptive analysis of frequency showed that marital status, age, education, income, and business status are the reasons behind women's labor performing informal economic activity in Palembang. Variable income opportunities attract women to work in the informal sector as well as flexibility and can be done independently (self-help). The conclusion of this study indicates that women that are educated, adult, and married tend to choose the fulfillment of the informal employment.
\end{abstract}

Keywords: workers, women's labor, informal sector

\section{Introduction}

The demographic bonus emerged in Indonesia within its results showed a higher number of productive population (ages 15-64) than non-productive population (ages 0-14 and > 64). This condition makes the dependency rate at the lowest position, which is $46 / 100$ people. It means that every productive person has one person or even less dependents. Other problems resulting from the demographic bonus are the increasing number of workers that are not comparable with the number of available jobs. Urban areas that tend to have more employment opportunities than rural areas are still a magnet for workers to compete for decent jobs.

The accumulation of labor in urban areas causes a surplus of labor. The urban tendency to use educated and skilled labor is another cause of labor difficulties in finding decent jobs. For workers who come from families who are able, usually willing to be unemployed to wait 
for the opportunity to get the expected job. However, for workers who come from lower middle class families, they will do any work as long as they can survive and work. Usually the work carried out is informal and subsistence.

The informal sector has the ability as a survival livelihood strategy for job seekers [1]. In addition, the informal sector is also able to absorb workers with various characteristics, ranging from workers who have never attended school to those with high education [2]. This is what causes the informal sector to continue to exist as an urban economic activity, even in a crisis and marginalized.

In the past, the informal sector was synonymous with rural economic activities, but since the industrial revolution and globalization, there has been a structural transformation of the economy, from the agricultural sector to the industrial sector and services. The impact of structural economic changes has caused the demand for labor in the agricultural sector to decline, so that rural residents migrate to urban areas [3]. At first the rural population migrated in hopes of getting better jobs in the city. However, because their educational background and skills are relatively low, they are unable to compete, and are forced to do work in the informal sector. Along with the development of the informal sector not only carried out by workers who are not in school, in Egypt, the informal sector is also carried out by highly educated workers as a stepping stone and fill the time to get the expected work [4].

The informal sector is a popular livelihood strategy for workers and is interesting to study, especially regarding the reasons for workers choosing to work in the informal sector. So far, it seems that working in the informal sector is only due to compulsion. Therefore, researchers are interested in exploring the reasons for the workforce in Palembang choosing to work in the informal sector. The workforce referred to in the study is women's labor who work in the informal sector. The researcher tried to conduct an interview to find out any evidence of reasonsbehind women's labor in Palembang, the city in South Sumatera province of Indonesia, decided to work in the informal sector.

\section{Methods}

This study used a descriptive quantitative research methodology. The population of this study encompassed all women's labor of informal sector in Palembang. Difficulties in obtaining data on informal sector workers have led researchers to conduct surveys directly into the field. Based on the survey results, it was found that the population of women's labor of informal sector in Palembang with a total of 700 people. Then the population is used as the research sample. So, the sample in the study is a population sample with the intention of getting more accurate information. Data collection is done using surveys and interviews. Then the collected data were analyzed by using a descriptive analysis of frequency that presented in pie charts and description. The researchers would like to present data on research results as they are, that is why this analysis of data is used. 


\section{Result and Discussion}

\subsection{Marital status}

The economic burden that increases after marriage and having family makes women the incentive to work. Consequently, the informal sector seems to be the choice for married women. The number of women working in the informal sector after marriage is proven by the results of the study. Based on the results of the study, the number of women working in the informal sector after marriage was 74 percent. While the other number is spread on unmarried 22 percent, death divorce 1 percent, and divorced 3 percent. This finding identifies an evidence of one reason for women to decide to work in the informal sector because of status after marriage which is presented in Figure 1 as follows:

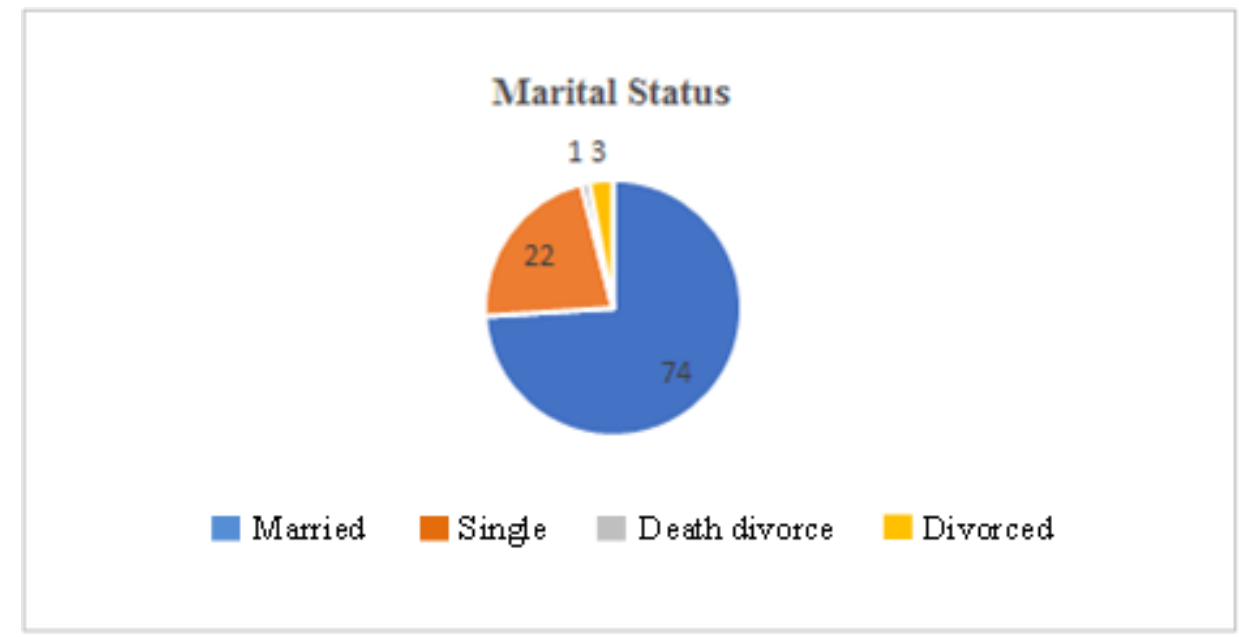

Fig. 1. Percentage of Women's Labor Status in Informal Sectors Source: 2017 Field Data Processed Results

In addition, husband's income that is erratic or mediocre also become one reason why married women have to work. The more family members, the higher the economic burden will be borne. Especially when you have children complying to school age. High school fees will make parents make various efforts to meet their needs. Including by involving the wife in work matters.The decision to work for married women will usually arise due to encouragement from the husband or personal will. In the study of Armansyah et al. (2018), some men encouraged their wives to work with reasons to help the economy or as a place for their wives to work and socialize. The boost will be even greater when the husband's work is not fixed and with uncertain income.

Moreover, the decision to work also arises from women's personal initiatives. This initiative will emerge with the high level of education possessed by a married woman. For this group of women work is a tool for them to refresh, because by working they can meet many people and get along. In addition, women workers with high education will feel disadvantaged if they do not work, so education will be a determining factor for women deciding to work in the informal sector.As a sector of work that offers freedom in time management, the informal sector is one way for women to take advantage of free time in addition to taking care of 
children and husbands. With the freedom to regulate work time, allowing married women to return to work by choosing the informal employment sector.

\subsection{Age}

The informal sector is a job area for adultworkers. The results of the study found a tendency for the adult worker, the greater the decision to get into informal employment. This statement is supported by research findings that show the percentage of women who work more in the adult age group, which is more than 30 years. Although the difference is not too far away from the young age group, this finding identifies that the tendency of older people to get into informal employment is greater. If examined further, the reason is the flexibility of time in the informal sector, which allows adult workers to work more relaxed and without pressure. In fact, the adult age group has no other choice. If the young age group can still have the opportunity to work in the formal sector or wait for opportunities to work in the formal sector, while in the adult age group the opportunity is getting smaller. As a result, the most rational survival strategy for adult women is to do any work that the informal sector offered. The following Figure 2 presents a percentage of women's labor age in informal sector:

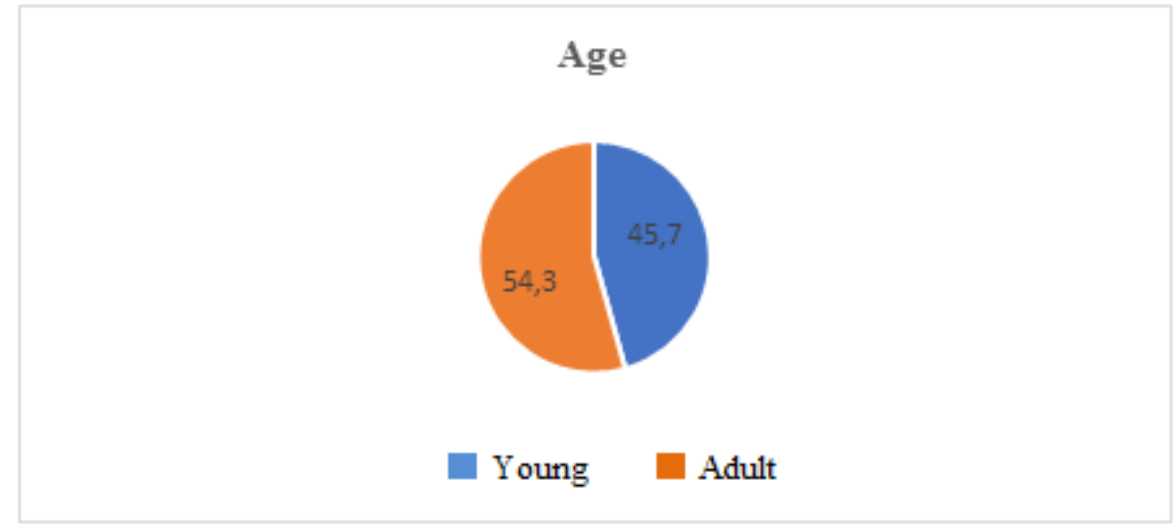

Fig. 2. Percentage of Women's Labor Age in Informal Sector Source: 2017 Field Data Processed Results

That is to say, age influencing women opportunity to get better job in formal sector. Younger groups do less informal sector work because they still have the opportunity to work in the formal sector. Although some young age groups have carried out activities in the informal sector, this activity is only a stepping stone while waiting for employment opportunities in the formal sector. This means that the more elderly, the less chance to get a job in the formal sector and will have an impact on the decision to carry out informal sector activities.

\subsection{Education}

Foregone, the informal sector was mostly carried out by workers with low education. As with the research conducted by Haris, the low level of education and lack of expertise certainly made it difficult for them to penetrate the formal sector. However, nowadays it is mostly done by workers with higher education or educated workers. This condition can be seen from research findings which show that 67 percent of women who work in the informal 
sector was highly educated with minimum requirement graduated from senior high school and above as described in Figure 3 :

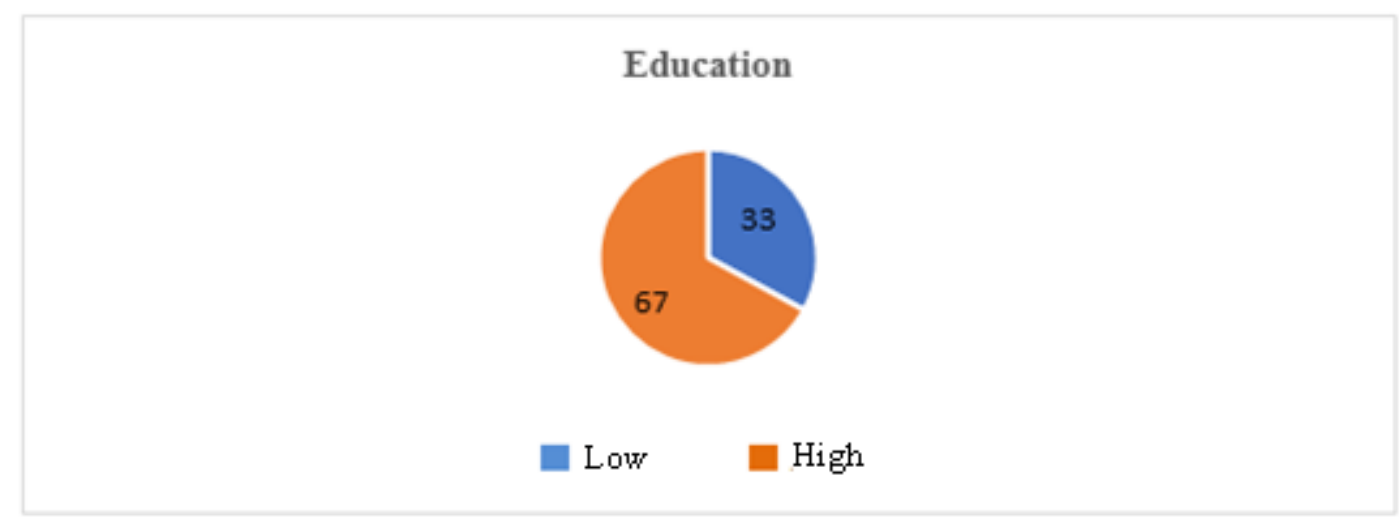

Fig. 3. Percentage of Women's Labor Education in Informal Sector

Source: 2017 Field Data Processed Results

This indicates that the informal sector is a type of work that is beginning to be sought by educated workers. However, the results of the study leads to two assumptions, first, the large number of educated women working in the informal sector indicates the development of the prospect of the informal sector, and second, the number of educated women get into the informal sector employment because they are forced to find decent jobs. As stated by Rini that the demands of work with educational qualifications and adequate skills in urban areas become an obstacle for job seekers in obtaining employment, those who initially wish to work in the formal sector eventually end up in the informal sector.

The findings of this study are in line with the results of the Barsoum study which found that many educated workers in Egypt got into the informal sector employment. However, the findings of Barsoum's study explain that the cause of many educated workers in Egypt get into informal sector employment due to the government's inability to prepare decent jobs for educated workers. As a result educated workforce has shifted to informal sector jobs. However, the activity was intended only temporarily while waiting for formal employment opportunities prepared by the government.

Based on observations and research results, there is a similar tendency of women's labor in the informal sector in Palembang. The informal sector activities that they do are not aimed at permanent activities but are intended to fill their spare time. And this reason is found mostly in unmarried women of informal sector workers and in the younger age group. But for married women, working in the informal sector is a rational choice because they can do their jobs as desired even from inside the house.

\subsection{Income}

The decision to choose a job is usually influenced by the level of income earned. The higher the promised income, the greater the urge to get into the employment. However, it seems that these factors have little effect on the type of informal sector work. This statement is supported by research findings which show that 78.3 percent of income earned by women in 
informal sector workers is below Rp. 400,000 per day. Even based on short interviews most of them earned Rp. 20,000 - Rp. 30,000 per day.

The speculative nature of income in the informal sector provides various income opportunities. It is evident that there are 6.4 percent of informal sector workers who get income above Rp. 800,000 per day. This means that groups of women workers in the informal sector with income above Rp. 800,000 per day offer that the informal sector can be used as a type of work not only to generate additional money or side jobs. The informal sector can even be used as the main type of work. Because it should be noted clearly, the existence of the informal sector in people's lives has a real contribution to the improvement of the socioeconomic conditions of the household, especially for women who is not highly educated. The percentage of women's labor income in informal sector is presented in Figure 4 as follows:

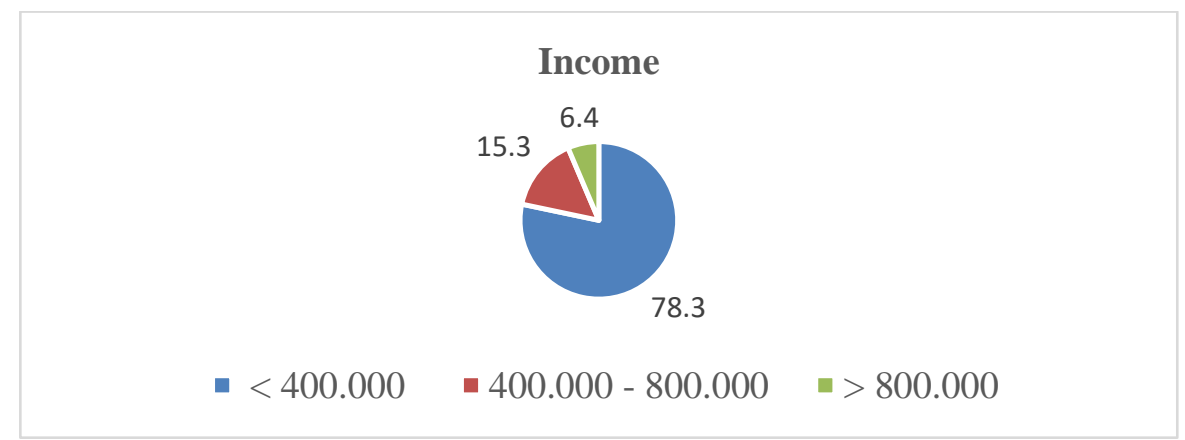

Fig. 4. Percentage of Women's Labor Income in Informal Sector Source: 2017 Field Data Processed Results

The ability of the informal sector to provide various income opportunities seems to attract the interest of women's labor of the informal sector. Income variations that indicate the potential to obtain a decent income make the informal sector seen as a part of the economy that must be developed in a country. This was revealed by Chen et al. that the informal sector must be part of urban livelihoods and contained in urban planning and local economic development.

This finding also indicates the use of technology by women's labor of the informal sector. They are able to run their businesses from inside the house with a wide marketing reach. The method is to use technology in the form of social media such as Facebook, Instagram and others. This statement according to Manning et al. is in accordance with the digital economic era that is currently developing. The use of social media-based technology is a new forum for workers to expand the promotion and marketing of their products. The ease in using social media is the trigger for many workers who use it. With a wide range, it is not impossible for women in the informal sector to earn large incomes even exceeding the income obtained in the formal sector.

\subsection{Business status}

Busyness in taking care of the household became the causes for women to think twice about working outside. To work as an employee with regulated working hours outside the housepush married women experience some difficulties and might lead a trigger tofamily conflicts. Therefore, the most rational reason if married women want to work is to get into the 
informal work. Because the informal sector has the flexibility of working time and can be done by his/herself.

The statement above is supported by the results of research that show that the reason women in Palembang got into the informal employment because it can be done by herself. The research findings show that women in the informal sector have a self-employment status of 98.3 percent, while the other 1.7 percent are workers or employees is shown in Figure 5 as follows:

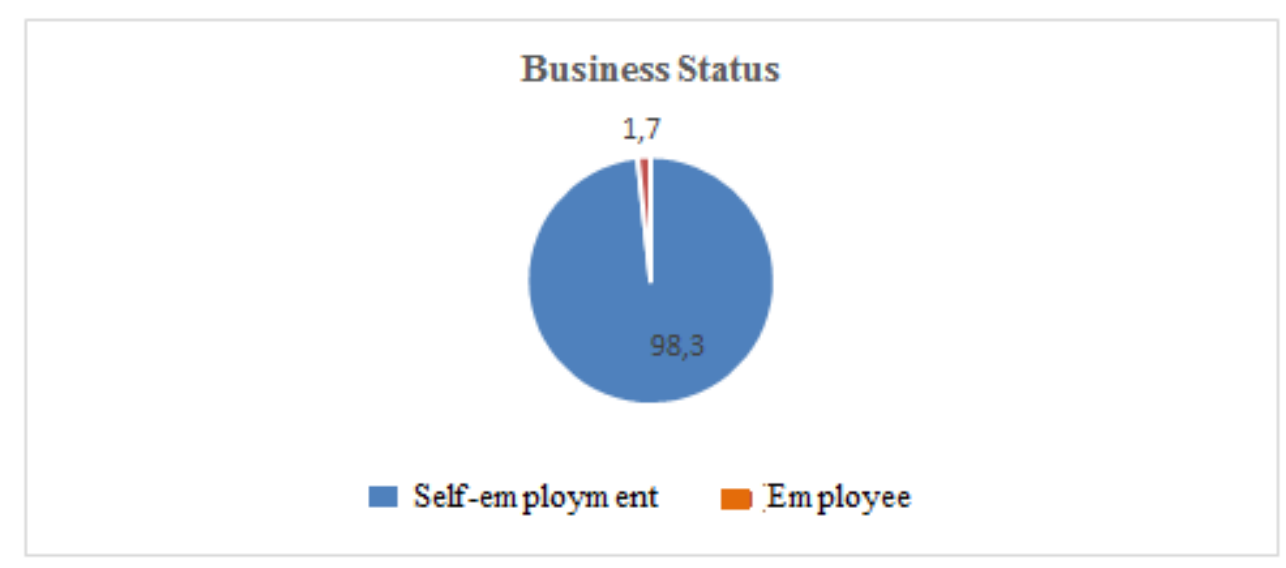

Fig. 5.Percentage of Business Status of Women's Labor in Informal Sector Source: 2017 Field Data Processed Results

The status factor of this business has to do with the status of women in the informal sector workers. As stated earlier in the status section of women informal sector workers that the majority of women who work have married status. This means that the most possible work for women who have been married is work in the informal sector with self-employment status.

Although there are a small number of women who work in the informal sector with the status of employee, the numbers are very small and are identified by many unmarried women. The freedom of time for unmarried women allows them to work as employee because they do not have a big responsibility in taking care of their family i.e. husband and children.

\section{Conclusion and Suggestion}

\subsection{Conclusion}

The decision of women's labor in Palembang, the city in South Sumatera Province of Indonesia, to work in the informal sector was caused by a number of reasons, namely marital status, age, education, income, and business status. Married women are more likely to get into informal jobs than unmarried women. Because the post-family economic burden increases, especially if their husbands have irregular jobs with erratic income. The older the age of women in Palembang, the greater the tendency to get into informal employment, because they have no other choice and the opportunity to get jobs in the formal sector is getting smaller.

Further reason is education. It's became the evidence when the researcher came to reality that the majority of women's labor in Palembang got into informal employment was highly 
educated with minimum requirement graduated from senior high school and above. However, this reason has to do with available job opportunities and time management. Difficulties in competing for decent work (formal) make women choose to do work in the informal sector as an alternative livelihood strategy. In addition, for married women, household affairs are an important responsibility, so they must manage the time between working and managing the household. Therefore, for these kind of women, working in the informal sector is the most appropriate type of work.

Speculative income opportunities seem to be the reason for women to work in the informal sector. There is no work desperation due to their belief in the sustenance set by God. It is evident that some of the women in the informal sector are able to earn more than Rp. 800,000 per day. The last reason women decide to work in the informal sector is because it can be done by herself. Informal sector work has the flexibility of time and can be done independently, so it allows women to work and take care of the household. It is very possible for women to work from home but make big profits, especially in today's digital era when information is at your fingertips.

\subsection{Suggestion}

Research on the informal sector must be directed at the realm of technology utilization as a material for consideration for further researchers in choosing problems related to the informal sector. In addition, it is also necessary to study life style changes in informal sector workers in the era of globalization. So far, the impression embedded in informal sector business actors is traditional, poor, and slum. Therefore, there is a need for research that can design the distinction of the informal sector in the earlier and the present day instead.

\section{References}

[1] Timofeyev, Y. (2013). The Effects of the Informal Sector on Income of the Poor in Russia. Social Indicators Research Soc Indic Res, 111(111). https://doi.org/10.1007/sl

[2] Armansyah, \& Aryaningrum, K. (2017). Analisis Karakteristik Demografi Pekerja Wanita Sektor Informal pada Era Masyarakat Ekonomi ASEAN di Kota Palembang. Populasi, 25(1), 52-63. Retrieved from https://jurnal.ugm.ac.id/populasi/article/view/32415/19530

[3] McGee, T. (2002). Invading, destroying and reconstructing. Bijdragen Tot de Taal-, Land- En Volkenkunde, 158(4), 637-652. Retrieved from https://www.jstor.org/stable/27867986

[4] Barsoum, G. (2016). "Job opportunities for the youth": Competing and overlapping discourses on youth unemployment and work informality in Egypt. Current Sociology, 64(3), 430-446. https://doi.org/10.1177/0011392115593614

[5] Hart, K. (1973). Informal Income Opportunities and Urban Employment in Ghana. Source: The Journal of Modern African Studies, 11(1), 61-89. Retrieved from http://www.jstor.org/stable/159873

[6] Leys, C. (1974). Interpreting African Underdevelopment: Reflection on the ILO Report on Employment, Incomes and Equality in Kenya. Manpower and Unemployment Research in Africa, 7(2), 18-28. Retrieved from https://www.jstor.org/stable/43390951

[7] Soebyakto, B. B., \& Armansyah. (2016). Migrant Women Working at Informal Sectors : 
Empirical Study in Kuto Batu Village, Ilir Timur Ii Palembang City. International Journal of Humanities and Social Science, 6(4), 125-137.

[8] Pitoyo, A. J. (1999). Pedagang Kaki Lima pada Masa Krisis. Populasi, 10(2). Retrieved from https://jurnal.ugm.ac.id/populasi/article/view/12485/9037

[9] Rini, H. S. (2012). Dilema Keberadaan Sektor Informal. Komunitas, 4(2), 200209.https://doi.org/10.15294/komunitas.v4i2.2415

[10] Armansyah, \& Mirna, T. (2018). Representasi Perempuan Pekerja Migran menurut Laki-laki di Kota Palembang. Populasi, 26(1), 26-38. https://doi.org/https://doi.org/10.22146/jp.38687

[11] Haris, D. M. (2011). StrategiPengembangan Usaha Sektor Informal DalamMendukungPertumbuhanEkonomi Dan PenanggulanganKemiskinan Di Perkotaan.Proceeding SimposiumNasionalOtonomi Daerah, 239-245.lab-ane.fisipuntirta.ac.id

[12] Chen, M. A., \& Vanek, J. (2013). Informal Employment Revisited: Theories, Data \&amp; Policies. Indian Journal of Industrial Relations, 48(3), 390-401. Retrieved from http://www.jstor.org.ezproxy.ugm.ac.id/stable/pdf/23510786.pdf?refreqid=search\%3A3 675f16ec4ed4d49bb12a336d5596185

[13] Manning, C., \& Devanto, P. (2018). Labour Market Developments in the Jokowi Years. Journal of Southeast Asian Economies, 35(2), 165-184. https://doi.org/10.1355/ae35-2d 